\title{
A Study to Assess the Prevalence of Tattooing and Awareness about Associated Health Risks among Students in a Selected College of District Ludhiana, Punjab
}

\author{
Amninder Kaur ${ }^{1}$, Babanpreet Kaur ${ }^{2}$, Chetna $^{3}$, Deepika ${ }^{4}$, Gurbir Kaur ${ }^{5}$, \\ Gurjasmeen Kaur ${ }^{6}$, Gurkirat Kaur ${ }^{7}$, Harmanpreet Kaur ${ }^{8}$, Harmanpreet Kaur', \\ Harmanpreet Kaur ${ }^{10}$ \\ ${ }^{1}$ Assistant Professor, Dayanand Medical College Hospital College of Nursing, Ludhiana \\ 2,3,4,5,6,7,8,9,10 Bachelor of Science in Nursing Students Dayanand Medical College Hospital College of Nursing, \\ Ludhiana \\ Corresponding Author: Gurbir Kaur
}

\begin{abstract}
Background: Tattooing has gained increasing popularity worldwide especially among adolescents and young adults. Worldwide, the evidence for tattooing has been found since old day. For thousands of years, human beings have marked their own skin, deliberately by permanently applying various types of pigment or ink. Tattoo inks usually consist of organic pigments, isopropyl alcohol and water. Tattooing is a practice in numerous cultures, for a variety of reasons. Sometimes tattoos are used as a proof of social status, or to identify one's membership. Therefore a study was undertaken to assess the prevalence of tattooing and awareness about associated health risks among students in a selected college of district Ludhiana, Punjab.

Objective: To assess the prevalence of tattooing and awareness about health risks associated with tattooing among students.

Material and Method: A descriptive research design was used to assess the prevalence of tattooing and awareness about associated health risks among students in selected college of district Ludhiana, Punjab. Convenience sampling technique was used to select sample of 144 students. Data was collected electronically (Google Forms). Analysis was done as per objectives of study by using descriptive and inferential statistics.

Result: The study results showed that Majority of the students (>80\%) were aware about common health risks related to tattooing. Age and socioeconomic status of students had significant association with awareness of health risk related to tattooing.

Conclusion: The study finding revealed that nearly (98.6\%) subjects had no tattoo. Hence it was concluded that the prevalence of tattooing among students is (1.4\%). In context of tattooing, (42.4\%) students were interested to have tattoo whereas, $(51.4 \%)$ were not interested and $(6.3 \%)$ were eager to try getting tattoo.
\end{abstract}

Keywords: Students, Tattoo, health risks.

\section{INTRODUCTION}

Tattooing has gained increasing popularity worldwide especially among adolescents and young adults. The evidence of tattooing has been found worldwide, since olden days ${ }^{[1]}$. They fall into three broad categories: purely decorative, symbolic and pictorial. The tattooing procedure is extremely painful. 
For thousands of years, human beings have marked their own skin deliberately by permanently applying various types of pigment or ink. The Egyptians were the first to use needle on body. The earliest known tattooed person was found in1991 in Italy, 58 tattoos were noted on his body.

As tattoo pigment lie encapsulated deep in the skin, tattoos are not easily destroyed even when the skin is burned. In India, the culture of tattoo has been seen to increase among adolescent and young adults as a fashion statement due to the growing use of body modification by media celebrities, sports icon and peers. However; this trend is accompanied by an increase in reported health complications. There are two levels of medical risks and complications that exist today due to tattoos, mild and advanced. Mild complaints are described as "Any unusual condition, sensation or visible reaction in the tattooed skin that differs from the normal skin of the same person". These side effects are common, often ignored and are usually treated at home. Adverse effects of tattooing can be sub divided as Acute aseptic inflammation, infectious risks bacterial and viral, allergic/ hypersensitivity and autoimmune type reactions, and other secondary effects.

The prevalence of tattooing worldwide was (48\%) highest in year 2018 among adolescents and young adults of Italy. In results of a research study conducted at Manipur it was reported that $(5.5 \%)$ prevalence of tattooing among adolescents and (87\%) subjects of stud had inadequate knowledge of health risks associated with it.

Ngai Sze Wong, Myanmar et.al (2019) conducted a descriptive study about knowledge of potential risk of blood borne viral infection and tattooing practice among adults. The overall self-reported prevalence of tattooing was $(19.5 \%)$ and $(80 \%)$ of participants knew at least one blood borne viral infection that could be transmitted from tattooing.
In India, there is mushrooming of tattoo parlors in the major cities like Mumbai, Delhi, etc. Tattoos applied in nonprofessional parlors remain common throughout the world thus creating more complications due to frequent procedures carried out without any knowledge of health and hygiene rules. Most of people who had undergone tattoo making were unaware of the health related risks associated with it, as per results of research studies.

Due to the variation and diversity in culture, a very few studies have been conducted in India. Number of people getting tattoo is increasing in India but it is not even included in Census. So, it is important to inform adolescents and young adults about possible health risks associated with tattooing.

\section{MATERIALS AND METHODS}

A descriptive research design was used to assess the prevalence of tattooing and awareness about associated health risks among students in a selected college of District Ludhiana, Punjab. After getting permission from ethical committee a sample of 144 college students was selected by using convenience sampling technique and data was collected from research subjects by self structured questionnaire to assess prevalence of tattooing and Checklist to assess awareness of health risks associated with tattooing by self report method. The data was analyzed as per objectives of research study by using inferential and descriptive statistics.

\section{RESULTS}

As per sociodemographic variables (68.1\%) students were in the age group of 18-22 years, $(90.3 \%)$ were female and $(57.6 \%)$ live in the urban area, (47.9\%) belonged to Sikh religion. As per their fathers education $(54.9 \%)$ graduate and (91\%) were working. Whereas (39.6\%) mothers of students had secondary education and (68.8\%) were not working. As per socio-economic status more than half 
(66\%) students belongs to upper middle family.

\section{Prevalence of tattooing}

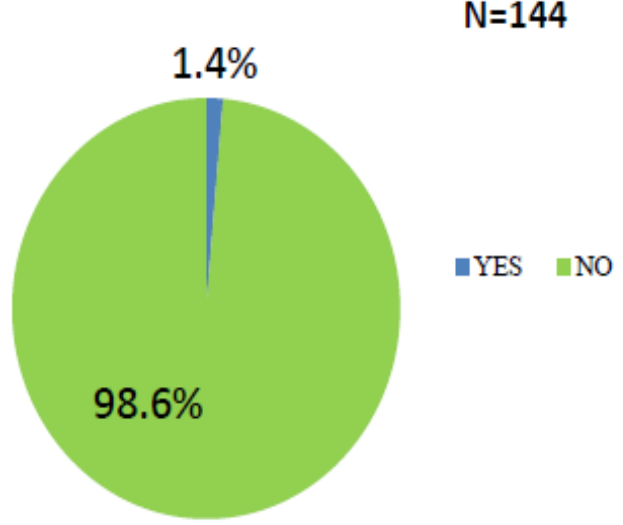

Fig 1: Prevalence of Tattooing among students.

Table 1: Frequency \& percentage Distribution of students as per their interest in tattooing.

\begin{tabular}{|l|ll|l|}
\hline $\begin{array}{l}\text { S. } \\
\text { NO. }\end{array}$ & \multicolumn{2}{|l|}{ STATEMENTS } & $\mathbf{f}(\%)$ \\
\hline 1. & \multicolumn{3}{|l|}{ In context of tattooing, you are: } \\
& a) & Interested & \\
& b) & Not interested & $61(42.4)$ \\
& c) & Eager to try & $74(51.4)$ \\
\hline 2. & \multicolumn{2}{|l|}{ You are not able to get a tattoo, despite } \\
& \multicolumn{2}{|l|}{ being interested, because: } & $9(6.3)$ \\
& a) & Have fear of needles & $19(13.2)$ \\
& b) & Cannot afford & $4(2.8)$ \\
& c) & Parents won't allow & $47(32.6)$ \\
& d) & Others & $74(51.4)$ \\
\hline 3. & \multicolumn{2}{|l|}{ Taking advice before tattooing is necessary: } & \\
& a) & No & $50(34.7)$ \\
& b) & Yes & $94(65.3)$ \\
\hline
\end{tabular}

Table 2: Frequency \& percentage distribution of students as per associated health risks related to tattooing.

\begin{tabular}{|c|c|c|}
\hline $\begin{array}{l}\text { S. } \\
\text { No. }\end{array}$ & STATEMENTS & f $(\%)$ \\
\hline 1. & \begin{tabular}{lc}
\multicolumn{2}{l}{ Tattooing is risky procedure: } \\
a) & No \\
b) & Yes
\end{tabular} & $\begin{array}{l}10(6.9) \\
134(93.1)\end{array}$ \\
\hline 2. & $\begin{array}{l}\text { Places and instruments used for tattooing } \\
\text { are always safe in terms of health and } \\
\text { hygiene: } \\
\begin{array}{ll}\text { a) } & \text { No } \\
\text { b) } & \text { Yes }\end{array}\end{array}$ & $\begin{array}{l}127(88.2) \\
17(11.7)\end{array}$ \\
\hline 3. & $\begin{array}{l}\text { Tattooing is less risky procedure than } \\
\text { surgery: } \\
\begin{array}{ll}\text { a) } & \text { No } \\
\text { b) } & \text { Yes }\end{array}\end{array}$ & $\begin{array}{l}76(52.8) \\
68(47.2)\end{array}$ \\
\hline 4. & $\begin{array}{l}\text { Tattoo removal can reduce the health risks } \\
\text { related to it: } \\
\begin{array}{ll}\text { a) } & \text { No } \\
\text { b) } & \text { Yes }\end{array}\end{array}$ & $\begin{array}{l}104(72.2) \\
40(27.8)\end{array}$ \\
\hline 5. & $\begin{array}{ll}\text { In case of complications due to tattooing, } \\
\text { you will: } & \\
\text { a) } & \text { Take advice from friends } \\
\text { b) } & \text { Self medication } \\
\text { c) } & \text { Ask a physician } \\
\text { d) } & \text { Ask your tattoo artist } \\
\text { e) } & \text { No need of any intervention } \\
\end{array}$ & $\begin{array}{l}1(0.7) \\
1(0.7) \\
129(89.6) \\
11(7.6) \\
2(1.4)\end{array}$ \\
\hline
\end{tabular}

Table 3: Frequency \& percentage distribution of students as per their awareness of associated health risks of tattooing.

\begin{tabular}{|c|l|c|c|}
\hline S.NO. & HEALTHRISKS & $\begin{array}{c}\text { NO } \\
\text { f(\%) }\end{array}$ & $\begin{array}{c}\text { YES } \\
\text { f(\%) }\end{array}$ \\
\hline 1. & Bleeding & $36(25.0)$ & $108(75.0)$ \\
\hline 2. & Allergies & $7(4.9)$ & $137(95.1)$ \\
\hline 3. & Scaring & $19(13.2)$ & $125(86.8)$ \\
\hline 4. & Abscess or cyst & $49(34.0)$ & $95(66.0)$ \\
\hline 5. & Dermatitis & $15(10.4)$ & $129(89.6)$ \\
\hline 6. & Tetanus & $19(13.2)$ & $125(86.8)$ \\
\hline 7. & Cellulitis & $41(28.5)$ & $125(86.8)$ \\
\hline 8. & Bacteremia or Septicemia & $16(11.1)$ & $128(88.9)$ \\
\hline 9. & Damage to oral cavity & $110(76.4)$ & $34(23.6)$ \\
\hline 10 & HIV/AIDS & $16(11.1)$ & $128(88.9)$ \\
\hline 11. & Viral hepatitis & $24(16.7)$ & $120(83.3)$ \\
\hline 12. & Impetigo & $57(39.6)$ & $87(60.4)$ \\
\hline 13. & Erysipelas & $71(49.3)$ & $73(50.7)$ \\
\hline 14. & Condylomata and Warts & $62(43.1)$ & $82(56.9)$ \\
\hline 15. & Herpes & $53(36.8)$ & $91(63.2)$ \\
\hline 16. & Glandular Fever & $82(56.9)$ & $62(43.1)$ \\
\hline 17. & Hemorrhage & $56(38.9)$ & $88(61.1)$ \\
\hline 18. & Bacterial Endocarditis & $72(50.0)$ & $72(50.0)$ \\
\hline 19. & Atypical Mycobacterium & $50(34.7)$ & $94(65.3)$ \\
\hline & infection & & \\
\hline 20. & Erythematic Nodules & $64(44.4)$ & $80(55.6)$ \\
\hline 21. & Septic Arthritis & $73(50.7)$ & $71(49.3)$ \\
\hline 22. & Tuberculosis & $98(68.1)$ & $46(31.9)$ \\
\hline 23. & Acute Glomerulonephritis & $112(77.8)$ & $32(22.2)$ \\
\hline 24. & Toxic Shock Syndrome & $82(56.9)$ & $62(43.1)$ \\
\hline 25. & Malignant skin cancer & $35(24.3)$ & $109(75.7)$ \\
\hline & & &
\end{tabular}

Figure 1 depicts that $(98.6 \%)$ subjects had no tattoo whereas, (1.4\%) students had tattoo so, prevalence of tattooing was (1.4\%) among students.

Table 1 interprets that in context of tattooing $(42.4 \%)$ students were interested to get tattoo, $(51.4 \%)$ not interested and $(6.3 \%)$ were eager to get a tattoo.(32.6\%) were not able to get tattooed because their parents wouldn't allow them ,(13.2\%) would not get tattooed due to fear of the needle and $(51.4 \%)$ had another reasons for not having a tattoo. $(65.3 \%)$ students were in favor of taking someone's advice before getting a tattoo.

Table 2 interprets that $(93.1 \%)$ students believe that tattooing would be less risky procedure. (88.2\%) students were disagreed that places and instruments used for tattooing were always safe in terms of health and hygiene while $(11.7 \%)$ students were agreed. According to $(52.8 \%)$ students tattooing was less risky procedure than surgery while $(47.2 \%)$ students agreed that tattooing had some health risks. According to $(72.2 \%)$ students tattoo removal could not reduce the health risks related to it while according to $(27.8 \%)$ students believed that 
health risks could be reduced after removing tattoo. Majority of the students $(89.6 \%)$ supported to consult the physician in case of complications, whereas $(7.6 \%)$ students said to talk with tattoo artist related to this, only $(1.4 \%)$ said there is no need of any intervention. Table 3 explains that more than $(75 \%)$ students were aware about the health risks related to tattooing, in which allergies (95.1\%), dermatitis (89.6\%), HIV/AIDS (88.9\%), septicemia (88.9\%).

\section{DISCUSSION}

In the present study prevalence of tattooing was found only $(1.4 \%)$ among students and (80\%) students had awareness about associated health risks related to tattooing.

Similar study was conducted in (2019) at University of Lagos by Olateru Olanrewaju the results of study showed that all participants $369(100 \%)$ were aware about health risks. (22.2\%) students had tattoo while $(77.8 \%)$ didn't had tattoo at the time of research.

In the present research study results shows that more than $(75 \%)$ students were aware about the health risks related to tattooing, in which allergies (95.1\%),dermatitis (89.6\%),HIV/AIDS (88.9\%), septicemia (88.9\%). Contrary results were reported by Singh Yumnam Ningthemba, Singh Akoijam Brogen, Oinam Joymati (2019) Conducted a study on prevalence of tattooing and knowledge about health risk associated with it among adolescent students and reported that $(99.5 \%)$ had heard of tattoo and $(87 \%)$ students had inadequate knowledge related to health risks of tattooing.

\section{CONCLUSION}

Results indicate a need for adequate information on health risks associated with tattooing among students therefore it's a need of time to plan and provide health education among youngsters to make them aware about accurate information about tattooing and its risks to health.

\section{ACKNOWLEDGEMENT}

We wish to acknowledge with a deep sense of gratitude and thanks to our Principal Dr (Mrs) Triza Jiwan, the mentor of the beginners of the research. She has given us foundation and made our roots firm in research. We are beholden by our research guide (Mrs) Amninder Kaur for her diligent and undiluted efforts to make the cruise sail smoothly and stir in the right direction, to make it reach the bank safely. We extend our special thanks and gratitude to all the panel members for their valuable suggestions given time to time and to all the experts for validating the tool for improving the project work. A hearty thanks to our parents and all the participants for helping in the process and being supportive throughout the study.

\section{Conflict of Interest: None}

\section{Source of Funding: None}

\section{Ethical Approval: Approved}

\section{REFERENCES}

1. Samyuktha P.S., Devi R. G, Priya A. J. A survey on awareness and perception about tattoos among college students. Drug Inventions Today [pdf] 2018; 10(1):27052707. Available from: wwwjprsolutions.info

2. Tattoo [online] [cited on 5 mar 2020]. Available from: www.wikipedia.org

3. Scott M. Tattoos. The ancient art of tattooing. [online] [Cited on 5 mar. 2020]. Available from www.tatring.com

4. KiaraA. Checklist before getting a tattoo. [online] [Cited on 13 mar 2020]. Available from: www.images.app

5. A brief introduction to tattoo art [online] [cited on 2 august 2020] Available from www.tatring.com

6. Sara Haq. The skin and the ink: tracing the boundaries of tattoo art in India [online] [Cited on 2 august 2020]. Available from: www.cidoc.mini.icom

7. Oinam J, Singh A B, Singh Y. Prevalence of tattooing and knowledge about health risks associated with it among adolescent school students in Manipur, North-eastern India: a cross sectional study. IJCMPH 2019; 6(2): 
Amninder Kaur et.al. A Study to assess the prevalence of tattooing and awareness about associated health risks among students in a selected college of District Ludhiana, Punjab.

774-770. Available from: http://dx.doi.org/10.18203/23946040.ijcmph20190205

8. Statistics [online] [Cited on 2 mar 2020]. Available from www.statista.com

9. Khunger, Niti; Molpariya, Anupama; Khunger, Arjun (2015)."Complications of Tattoos and Tattoo Removal: Stop and Think Before you ink". Journal of Cutaneous and Aesthetic Surgery. 8 (1): 30- 36.Doi: 10.4103/09742077.155072.ISSN09742077.PMC4411590.PMID25949020.

10. Quaranta A, Napoli C, Fasano F, Montagna C, Caggiano G, Montagna MT. Body piercing and tattoos: a survey on young adults' knowledge of the risks and practices in body art. BMC Public Health 2011. Available from: http://www.biomedcentral.com/14712458/11/774.

How to cite this article: Kaur A, Kaur B, Chetna et.al. A Study to assess the prevalence of tattooing and awareness about associated health risks among students in a selected college of District Ludhiana, Punjab. Int J Health Sci Res. 2021; 11(9): 55-59. DOI: https://doi.org/10. 52403/ijhsr.20210908

$* * * * * *$ 